\title{
Carbon Balance of Turfgrass Systems in Response to Seasonal Temperature Changes Under Different Mowing Heights
}

\author{
Yali Song ${ }^{1}$ \\ College of Forestry, Beijing Forestry University, Beijing 100083, China; and the Department of Plant \\ Biology and Pathology, Rutgers University, New Brunswick, NJ 08901 \\ Patrick Burgess ${ }^{1}$ \\ Department of Plant Biology and Pathology, Rutgers University, New Brunswick, NJ 08901
}

Hairong Han

College of Forestry, Beijing Forestry University, Beijing 100083, China

Bingru Huang ${ }^{2}$

Department of Plant Biology and Pathology, Rutgers University, New Brunswick, NJ 08901

AdDitional INDEX wORDs. kentucky bluegrass, photosynthesis, respiration, carbon fixation, climate change

\begin{abstract}
Turfgrass growth and physiological activities are sensitive to temperatures and are affected by mowing height. Increasing temperatures associated with global climate change may limit photosynthetic capacity of established turfgrass stands. The objective of this study was to determine the effects of mowing height on carbon exchange of a turfgrass system and consequential effects on turfgrass growth in response to temperature variations across the growing season in kentucky bluegrass (Poa pratensis cv. Baron) stands. Mature (8 years old) turfgrass was mowed at $7.6 \mathrm{~cm}$ [high mowing height (HM)] or $3.8 \mathrm{~cm}$ [low mowing height (LM)] during 2012 and 2013. Both LM and HM plots displayed significant decline in turf quality (TQ), shoot biomass, and canopy photosynthetic rate (Pn) with increasing air temperature above 23-24 ${ }^{\circ} \mathrm{C}$ in both years and the decline was more pronounced for $\mathrm{LM}$ plots. Turf plots were carbon emitters when total respiration rate of shoots, roots, and soil $\left(R_{\text {total }}\right)$ exceeded canopy Pn under high temperatures during July-September but maintained net carbon gain during cooler seasons (May and June) due to greater Pn to $R_{\text {total }}$ ratio (Pn: $R_{\text {total }}$ ). Lowering mowing height accelerated carbon loss by reducing canopy Pn, particularly under high temperatures. Our results suggested that whether mature turfgrass stands fix or emit carbon is heavily dependent on interaction between seasonal temperatures and mowing height gauging whole-stand photosynthetic capacity. Furthermore, increasing mowing height during summer months may offset the deleterious effects of high temperature by maintaining positive carbon balance within the turfgrass system.
\end{abstract}

Global climate change encompasses different environmental factors and is predicted to increase the frequency and severity of high-temperature events associated with increasing atmospheric $\mathrm{CO}_{2}$ concentrations (Solomon et al., 2007). Plants fix carbon from the atmosphere to drive photosynthetic carbohydrate production, which supports virtually all aspects of plant growth while a large portion of the fixed carbon is respired from aboveground and belowground components (Taiz and Zeiger, 2010). The capacity for a managed plant ecosystem to efficiently fix carbon from the atmosphere is highly dependent on both the composition of plant species and management practices (Cole et al., 1996).

Managed turfgrass occupies over $35,000 \mathrm{~km}^{2}$ or $1.9 \%$ of land within the continental United States as of the year 2005 (Milesi et al., 2005) and the total area devoted to turf is expected to further increase throughout the world due to urban expansion and the widely recognized environmental, aesthetic, and recreational benefits of turfgrass ecosystems. Environmental and cultural

Received for publication 7 Apr. 2015. Accepted for publication 18 May 2015. The scholarship support from Chinese Scholarship Council for Yali Song to conduct research at Rutgers University is greatly appreciated. Authors also wish to thank Rutgers Center for Turfgrass Science for funding support of this study.

${ }^{1}$ These authors contributed equally to this work.

${ }^{2}$ Corresponding author. E-mail: huang@aesop.rutgers.edu. factors, particularly temperature and mowing height, can have profound impact on turfgrass growth and subsequent physiological and environmental functions. The optimal air temperature for cool-season grass growth is $16-24^{\circ} \mathrm{C}$ for shoot growth and 16-22 ${ }^{\circ} \mathrm{C}$ for root growth (Beard, 1973; Steinke and Ervin, 2013). Temperatures above the optimal range inhibit leaf photosynthesis and increase respiration rates of all tissues leading to carbohydrate depletion within the plant system of cool-season turfgrass species (DaCosta and Huang, 2013). Mowing height governs total leaf area available for photosynthesis and therefore has a direct effect on turf performance as demonstrated in creeping bentgrass (Agrostis stolonifera) which maintained acceptable visual quality during summer months when mowed at $4.0 \mathrm{~mm}$ but poor visual quality at 3.0 $\mathrm{mm}$ height (Liu and Huang, 2003). In a controlled climate growth chamber study, Huang and Gao (2000) showed that high temperatures impaired photosynthesis and reduced carbohydrate production for three creeping bentgrass cultivars, leading to significant decline in TQ.

The net carbon balance of an ecosystem depends on the magnitude of $\mathrm{CO}_{2}$ uptake by photosynthesis and $\mathrm{CO}_{2}$ release by shoot, root, and soil respiration, which can vary with seasonal temperature changes and plant/soil conditions (Lohila et al., 2003). There has been significant previous research regarding 
carbon fixation capacity and carbon balance of natural grassland ecosystems. For example, in natural grasslands, such as central Mongolian grass steppe, it was reported that annual net ecosystem carbon exchange rate is partitioned into $179 \mathrm{~g} \cdot \mathrm{m}^{-2}$ carbon per year of photosynthesis and $138 \mathrm{~g} \cdot \mathrm{m}^{-2}$ carbon per year of respiration, suggesting that unmanaged grassland is a weak carbon sink (Li et al., 2005). Maximal seasonal photosynthetic carbon gains and respiratory carbon loss were 10.1 and 6.5 $\mathrm{g} \cdot \mathrm{m}^{-2}$ carbon per year, respectively, across two growing seasons for a Mediterranean annual grassland in California, and significantly higher levels of respiratory carbon loss occurred as a result of increasing air temperature during late June ( $\mathrm{Xu}$ and Baldocchi, 2004). For managed turfgrass systems, previous studies have focused on quantifying organic carbon sequestration or long-term carbon storage in soil and organic matter (Bandaranayake et al., 2003; Milesi et al., 2005; Qian and Follett, 2002; Qian et al., 2003, 2010; Townsend-Small and Czimczik, 2010). However, little is known regarding the capacity of managed turfgrass stands for short-term carbon gain or carbon loss with respect to the balance of canopy photosynthetic $\mathrm{CO}_{2}$ uptake and whole-plant respiratory $\mathrm{CO}_{2}$ release (Baird, 2011) and how interacting environmental factors (i.e., seasonal temperatures) and cultural practices (i.e., mowing) may affect carbon balance of established turfgrass systems.

A better understanding of carbon balance for mature turfgrass stands responding to different mowing heights across multiple seasons is important for assessing the potential of urban turfgrass systems for carbon fixation or loss and for developing effective management practices to promote heathy turfgrass with high capacity for carbon fixation throughout the growing seasons. The specific objective of this research was to determine effects of mowing height on turfgrass growth and carbon balance in terms of carbon fixation through canopy photosynthesis and carbon loss through respiration of the whole-system of turfgrass stands (shoots, root, and soils) in response to changes in temperatures during the growing season in mature kentucky bluegrass stands. The overall aim was to understand real-time carbon balance of a perennial turfgrass stand mowed at two different heights under seasonal temperature changes across multiple growing seasons in New Jersey.

\section{Materials and Methods}

Plant material and growth conditions. The experiment was performed from May to Oct. 2012 and 2013 at the Rutgers University turfgrass research farm in North Brunswick, NJ. Individual plots $(2.5 \times 3.0 \mathrm{~m})$ of mature $(8$ years old) kentucky bluegrass (cv. Baron) were mowed twice per week at either $7.6 \mathrm{~cm} \mathrm{(HM)} \mathrm{or} 3.8 \mathrm{~cm}$ (LM) with clippings removed. During weeks when measurements were performed, plot mowing was performed daily $\approx 16 \mathrm{~h}$ before data collection (night prior). The soil type was a Nixon sandy loam consisting of $41 \%$ sand, $39 \%$ silt, and $20 \%$ clay with $2.5 \%$ organic matter and $1.4 \%$ organic carbon (Rutgers University Soil Testing Laboratory, Oct. 2013 (B)
New Brunswick, NJ). Granular fertility (16N-1.7P-6.6K) was applied once during April for spring green-up and again midJune for summer fertility during 2012 and 2013 at $3.2 \mathrm{~g} \cdot \mathrm{m}^{-2}$ nitrogen. No pesticides were applied to the site as to avoid possible confounding effects and there was minimal disease occurrence during both years of study. Irrigation was applied three times per week throughout the year to maintain soil water content near field capacity $(35 \%)$ and the experimental site was never subjected to any level of drought stress because of regular irrigation.

Daytime air temperature and irradiance levels were continuously monitored via the Campbell Scientific (Logan, UT) weather station operating on Mesonet network (New Brunswick, NJ; lat. $40.4797^{\circ} \mathrm{N}$, long. $-74.4254^{\circ} \mathrm{W}$ ) from July to Oct. 2012 and May to Oct. 2013. Soil temperature was continuously monitored using soil thermometers $(15 \mathrm{~cm}$ depth; Fisher Scientific, Pittsburgh, PA) from July to Oct. 2012 and May to Oct. 2013. Average air and soil temperatures and irradiance levels from 1000 to $1500 \mathrm{~h}$ on sunny days when measurements were performed are provided for both years of study (Fig. 1).

GrowTH AND Gas EXCHANGE MEASUREMENTs. Visual evaluation of TQ was performed as an indicator of overall turfgrass performance on a scale of 1 to 9 with 1 being brown and dead turf, 6 being the minimum acceptable quality level, and 9 being green and healthy turf. Turf quality ratings were based on parameters such as canopy uniformity, density, visual attractiveness, and color (Beard, 1973) from July to Oct. 2012 and May to Oct. 2013.

Gas exchange parameters, including canopy net Pn and respiration rate of the whole turfgrass system (shoots, roots, and soil) were measured between 1000 and $1500 \mathrm{~h}$ on five consecutive sunny days of each month from May to Oct. 2012 and 2013. Measurements were collected from five subareas (10 $\mathrm{cm}$ diameter) as five subsamples in each of the four replicated plots for each mowing height treatment. Uniform turfgrass areas within each plot were randomly selected for gas exchange measurement and no subarea was reused across all seasons and both years of study. Setup and measurements of canopy $\mathrm{Pn}$ and $\mathrm{R}_{\text {total }}$ followed the design and procedures described in Liu and Huang (2001), Lohila et al. (2003), and Baird (2011) with modifications in chamber dimensions and air flow control. On days when measurements were recorded, a steel collar (10 cm height, $10 \mathrm{~cm}$ diameter) was inserted into the soil on each subplot to a depth of $5 \mathrm{~cm}$. The turfgrass
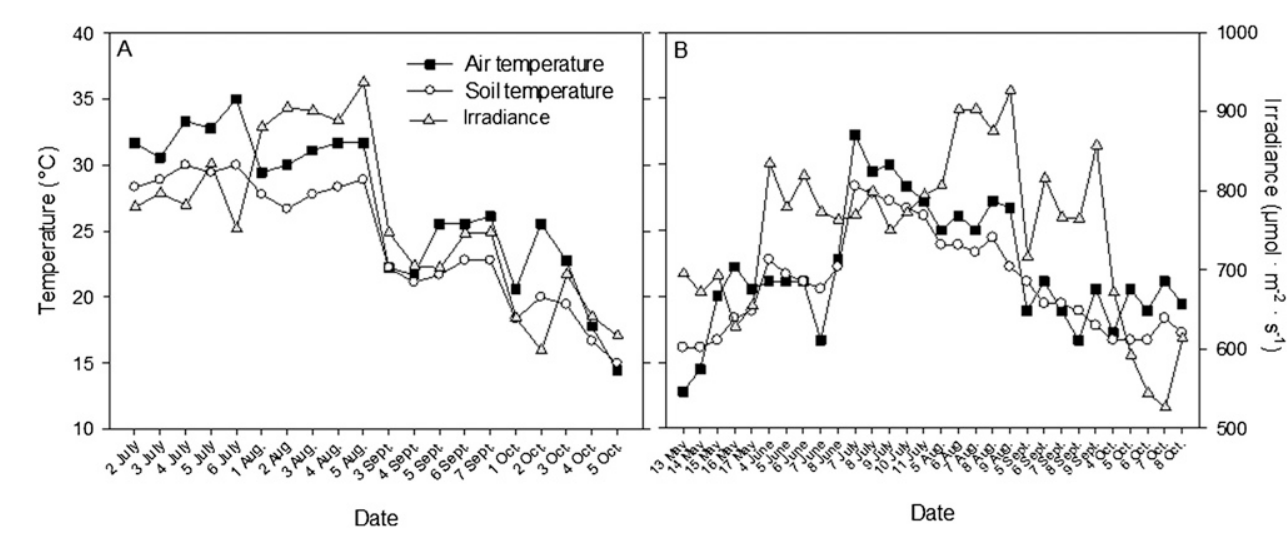

Fig. 1. Daily maximum air (solid square) and soil (open circle) temperature and solar irradiance (shaded triangle) during the periods of growth and gas exchange measurements from July to Oct. 2012 (A) and May to 
canopy was enclosed in a transparent plexiglass chamber (10 cm diameter) with the top sealed with clear plastic film allowing light penetration into turf canopy, the bottom fitted to the steel collar with a water groove to make the chamber airtight, and the side directly connected to a portable infrared (IR) gas analyzer (LI-6400; LI-COR, Lincoln, NE). A batteryoperated fan installed within the plexiglass chamber was running constantly during gas exchange measurements to facilitate air flow and maintain temperature and humidity equilibrium between the plexiglass chamber, gas analyzer, and surrounding ambient air. Once the plexiglass chamber was fitted to steel collar, the chamber and analyzer were allowed to reach equilibrium with surrounding ambient air for minimum of 5 min and then canopy Pn was recorded. Coinciding with batteryoperated fan within plexiglass chamber, the gas analyzer was set to $700 \mu \mathrm{mol} \cdot \mathrm{s}^{-1}$ flow rate. Following Pn measurement, an opaque canvas was placed atop turfgrass and $\mathrm{R}_{\text {total }}$ recorded after $20 \mathrm{~min}$ darkness. The $\mathrm{R}_{\text {total }}$ measures the total ecosystem respiration, which included plants and associated soil microorganisms as part of the total plant system in natural field conditions (Lohila et al., 2003). Following data collection, all steel collars were removed from the research site as to not interfere with mowing practices. Air temperature was logged simultaneously with gas exchange measurements and plotted against canopy $\mathrm{Pn}, \mathrm{R}_{\text {total }}$, or $\mathrm{Pn}: \mathrm{R}_{\text {total }}$ to closely reflect gas exchange responses to seasonal changes in temperature at two mowing heights. Before the steel collar was removed from soil, shoots were severed at the soil line within the area where gas exchange measurements were collected, dried in an oven at $80^{\circ} \mathrm{C}$ for $7 \mathrm{~d}$, and weighed on a balance to determine shoot biomass. Shoot biomass was evaluated from July to Oct. 2012 and May to Oct. 2013.

Statistical Analysis. Plots were arranged in a randomized complete block design with four replicated plots per mowing height. Five subsample measurements were conducted per individual plot in a sequential manner of one subsample measurement per each replicated plot per day, totaling $5 \mathrm{~d}$ of measurements per month in 2012 and 2013. Treatment effects were determined by analysis of variance according to the general linear model procedure of SAS (version 9.1; SAS Institute, Cary, NC). Differences between means were separated by Fisher's protected least significant difference test at the $0.05 P$ level.

\section{Results}

AIr AND SOIL TEMPERATURE AND IRRADIANCE LEVELS DURING THE PERIODS OF GROWTH AND GAS EXCHANGE MEASUREMENTS. Air temperature was within the optimal range for growth of coolseason plant species during Sept. and Oct. $2012\left(24.2\right.$ and $20.2^{\circ} \mathrm{C}$, respectively), but was above the optimal range during July and Aug. 2012 (32.6 and $30.7{ }^{\circ} \mathrm{C}$, respectively) (Fig. 1A). The average air temperatures during the periods of growth and gas exchange measurements were slightly lower during 2013 than 2012 , but were still above levels for optimal growth during July and August (29.4 and $26.0{ }^{\circ} \mathrm{C}$, respectively) (Fig. 1B). During May, June, Sept., and Oct. 2013, air temperatures were $18.0,20.5,19.2$, and $19.4{ }^{\circ} \mathrm{C}$, respectively. Soil temperature was within the optimal range for growth of cool-season plant species during Sept. and Oct. 2012 (22.0 and $17.9{ }^{\circ} \mathrm{C}$, respectively), but was above the optimal range during July and Aug. 2012 (29.3 and $28.9^{\circ} \mathrm{C}$, respectively) (Fig. 1A). The average soil temperatures during the periods of growth and gas exchange measurements were slightly lower during 2013 than 2012 , but were still above levels for optimal growth during July and August (27.2 and $23.6{ }^{\circ} \mathrm{C}$, respectively) (Fig. 1B). During May, June, Sept., and Oct. 2013, soil temperatures were 17.2, $21.7,19.3$, and $17.1^{\circ} \mathrm{C}$, respectively. Average irradiance levels increased during May and June, reached highest levels during the summer months of July and August, and showed a decreasing trend during September and October for both 2012 and 2013 seasons (Fig. 1A and B, respectively).

As the objective of this study was to examine the effects of mowing height on carbon exchange of the turf system and consequential effects on turfgrass growth in response to temperature variations across the growing season from May to October, gas exchange parameters were plotted as a function of average air temperatures during the day when measurements were taken throughout the growing season, as air temperature varied diurnally and in different growing seasons. Therefore, the gas exchange figures are described as responses to naturally changing temperatures for both years of study and described in the results below. Turf quality and shoot growth are cumulative criteria which do not respond quickly to temperature level and are therefore plotted as a function of date.

RESPONSES OF CANOPY PN AND THE WHOLE-SYSTEM RESPIRATION RATE TO SEASONAL TEMPERATURE CHANGES UNDER HIGH AND LOW MOWING CONDITIONS. Canopy Pn increased to the maximum from 12 to $24{ }^{\circ} \mathrm{C}$ and decreased from 25 to $35{ }^{\circ} \mathrm{C}$ during 2012 for both HM and LM plots (Fig. 2A). Canopy Pn increased by $109 \%$ and $203 \%$ from 12 to $24{ }^{\circ} \mathrm{C}$ and decreased by $55 \%$ and $49 \%$ from 24 to $35{ }^{\circ} \mathrm{C}$ for HM and LM plots, respectively, during 2012. During 2013, canopy Pn showed a $28 \%$ increase from 13 to $24{ }^{\circ} \mathrm{C}$ for $\mathrm{HM}$ plots and $98 \%$ increase from 13 to $22{ }^{\circ} \mathrm{C}$ for LM plots (Fig. 2B). There was a 30\% decrease in canopy $\mathrm{Pn}$ from 24 to $33{ }^{\circ} \mathrm{C}$ for $\mathrm{HM}$ plots and $48 \%$ decrease from 22 to $33{ }^{\circ} \mathrm{C}$ for LM plots during 2013. Canopy Pn was significantly lower in LM plots than in HM plots across all temperatures in both years.

Respiration rate of shoots, roots, and soil increased by $79 \%$ and $86 \%$ between 12 and $22{ }^{\circ} \mathrm{C}$ for HM and LM plots, respectively, and decreased only for HM plots thereafter with increasing temperatures up to $25^{\circ} \mathrm{C}$ in 2012 (Fig. 3A). $\mathrm{R}_{\text {total }}$ decreased by $44 \%$ and $39 \%$ for HM and LM plots, respectively, between 13 and $20^{\circ} \mathrm{C}$ in $\mathrm{HM}$ plots and 13 and $19^{\circ} \mathrm{C}$ in LM plots of 2013 (Fig. 3B). $\mathrm{R}_{\text {total }}$ increased by $101 \%$ and $49 \%$ for HM and LM plots, respectively, with increasing temperatures in 2013.

$\mathrm{R}_{\text {total }}$ exceeded canopy Pn in $\mathrm{HM}$ plots from 12 to $22^{\circ} \mathrm{C}$ and again as temperature increased above $29^{\circ} \mathrm{C}$ in 2012 and above $27{ }^{\circ} \mathrm{C}$ in 2013 (Fig. 4A). Under LM treatment, $\mathrm{R}_{\text {total }}$ exceeded canopy Pn from 12 to $21^{\circ} \mathrm{C}$ and again as temperature increased above $26^{\circ} \mathrm{C}$ in 2012 and above $23{ }^{\circ} \mathrm{C}$ in 2013 (Fig. 4A and B, respectively). The ratio of canopy $\mathrm{Pn}$ to $\mathrm{R}_{\text {total }}$ of $\mathrm{HM}$ plots was maintained above 1.0 between 23 and $28^{\circ} \mathrm{C}$ in 2012 and between 17 and $27^{\circ} \mathrm{C}$ in 2013 . The ratio of canopy Pn to $R_{\text {total }}$ of LM plots was maintained above 1.0 between 22 and $26{ }^{\circ} \mathrm{C}$ in 2012 and between 17 and $23^{\circ} \mathrm{C}$ in 2013 .

RESPONSES OF TQ AND SHOOT BIOMASS TO SEASONAL TEMPERATURE CHANGES UNDER HIGH AND LOW MOWING CONDITIONS. Visual TQ was above the minimum acceptable level for HM and LM plots during September whereas only HM maintained acceptable quality in Oct. 2012 (Fig. 5A). Quality of all plots declined below the minimum acceptable level during July and August though HM plots had significantly higher TQ 

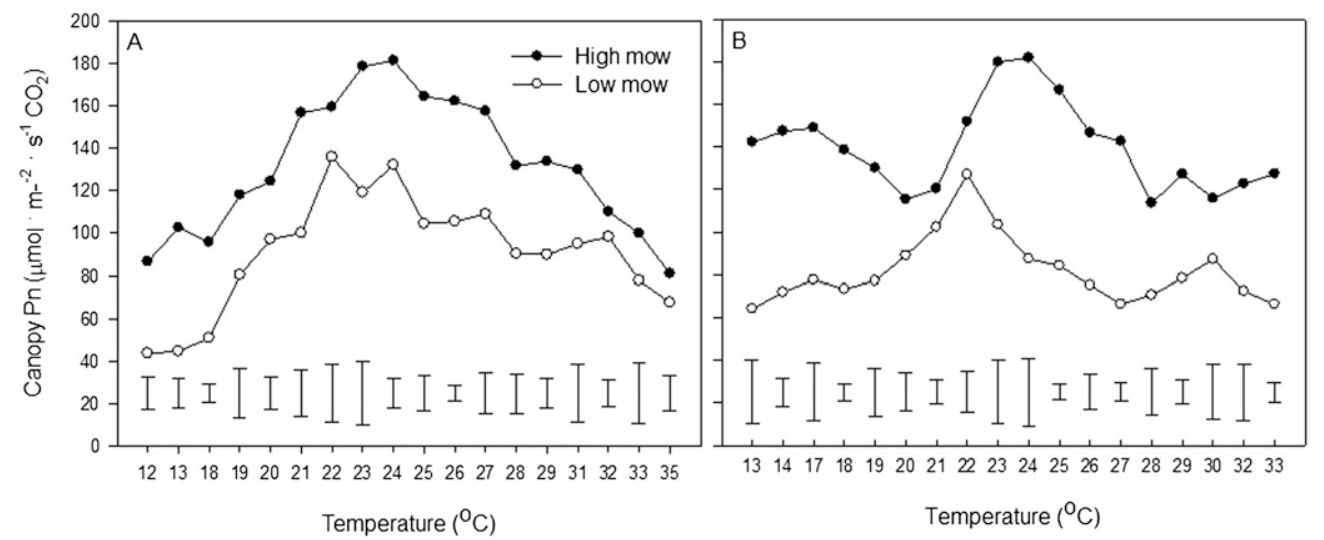

Fig. 2. Responses of canopy photosynthetic rate (Pn) to temperature changes for kentucky bluegrass mowed at high $(7.6 \mathrm{~cm})$ and low $(3.8 \mathrm{~cm})$ heights from May to Oct. 2012 (A) and 2013 (B). Vertical bars indicate least significant difference (LSD) values $(P=0.05)$ for treatment comparisons at a given temperature.
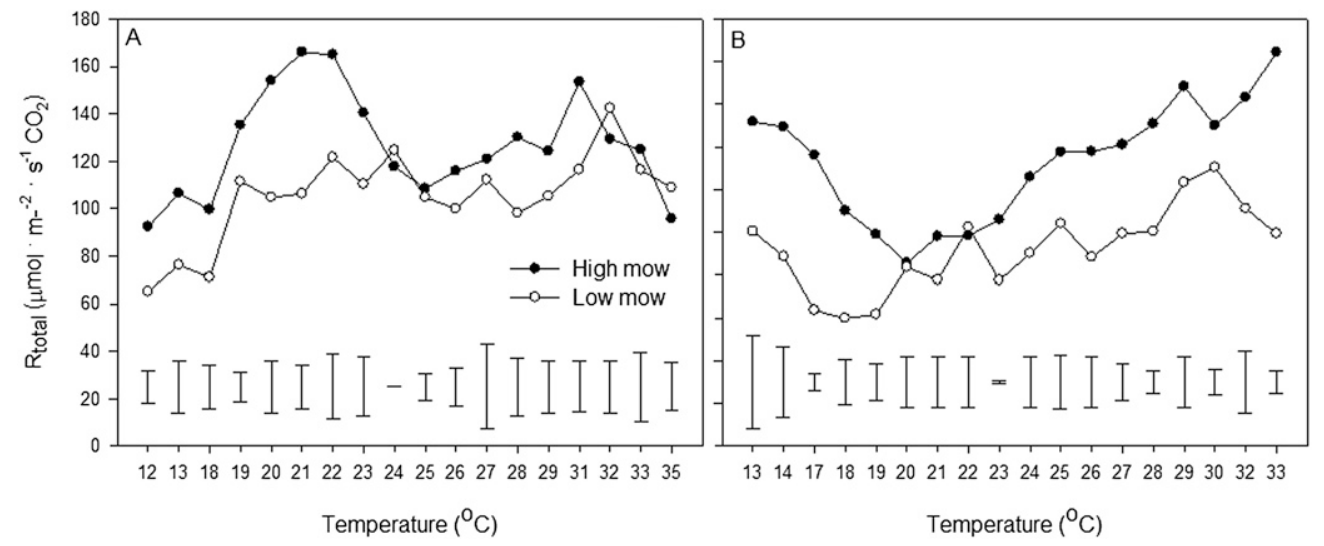

Fig. 3. Responses of total ecosystem respiration $\left(\mathrm{R}_{\text {total }}\right)$, which included plants and associated soil microorganisms as part of the total plant system to temperature changes for kentucky bluegrass mowed at high $(7.6 \mathrm{~cm})$ and low $(3.8 \mathrm{~cm})$ heights from May to Oct. 2012 (A) and 2013 (B). Vertical bars indicate least significant difference (LSD) values $(P=0.05)$ for treatment comparisons at a given temperature.
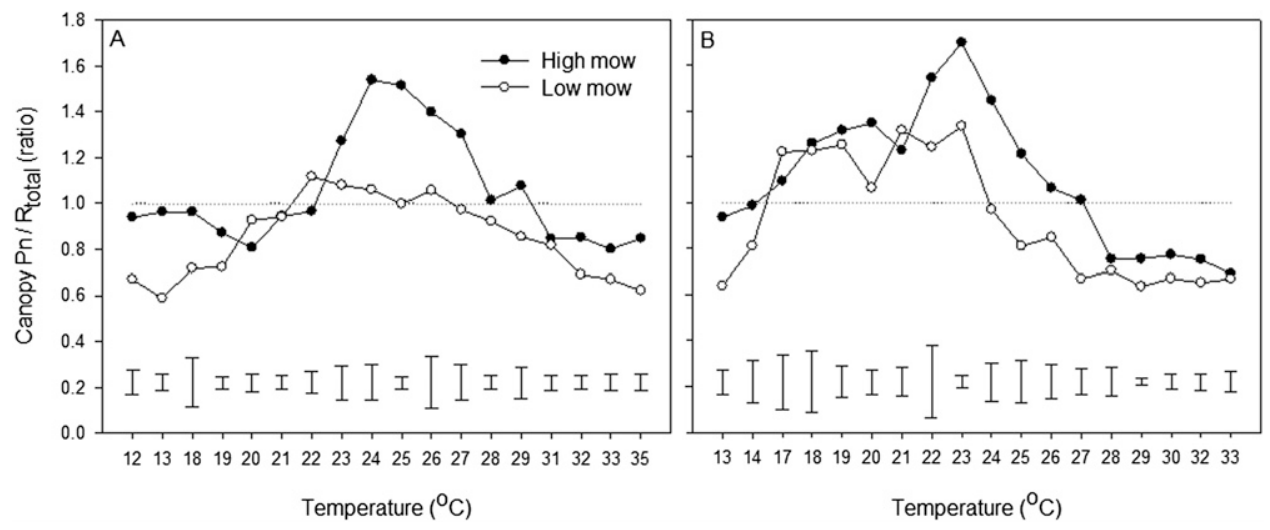

Fig. 4. Responses of canopy photosynthetic rate $(\mathrm{Pn})$ to total ecosystem respiration $\left(\mathrm{R}_{\text {total }}\right)$ ratio $\left(\mathrm{Pn}: \mathrm{R}_{\text {total }}\right)$ for kentucky bluegrass mowed at high $(7.6 \mathrm{~cm})$ and low $(3.8 \mathrm{~cm})$ heights from May to Oct. $2012(\mathbf{A})$ and $2013(\mathbf{B})$. Vertical bars indicate least significant difference (LSD) values $(P=0.05)$ for treatment comparisons at a given temperature.

than LM plots on all dates with the greatest difference occurring during July and August (16.8\% and $28.7 \%$ higher, respectively) in 2012. Visual TQ was above the minimum acceptable level for HM and LM plots during June and September whereas only HM maintained acceptable quality in May and Oct. 2013 (Fig. 5B). Quality of all plots declined below the minimum acceptable level during July and August though HM plots had significantly higher TQ than LM plots on all dates with the greatest difference occurring during July and August $(27.2 \%$ and $30.2 \%$ higher, respectively) in 2013. Shoot biomass was significantly lower for LM compared with HM plots across all dates in 2012 and 2013 (Fig. 6A and B, respectively). There was a slight decrease in shoot biomass for both HM and LM plots during the hottest times of each year (July-August) and highest shoot biomasses were recorded during cooler weather of Sept. and Oct. 2012 and May, June, Sept., and Oct. 2013.

\section{Discussion}

Changing temperatures during the growing season have significant impact on turfgrass growth and carbon exchange (Beard, 1973; Turgeon, 2008). Canopy Pn of creeping bentgrass was at its maximum at $20-24{ }^{\circ} \mathrm{C}$ in a controlled-environment 


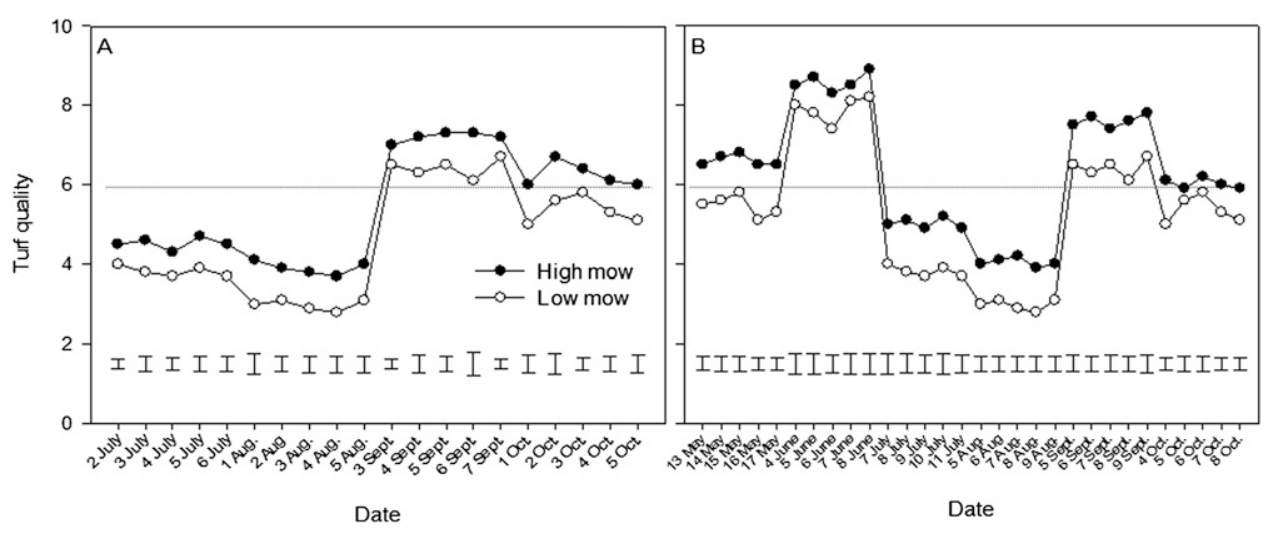

Fig. 5. Visual turf quality (TQ) (rated on a scale of 1 to 9 , where $1=$ brown and dead turf, $6=$ minimum acceptable quality level, and $9=$ green and healthy turf) of kentucky bluegrass mowed at high $(7.6 \mathrm{~cm})$ and low $(3.8 \mathrm{~cm})$ heights from July to Oct. 2013 (A) and May to Oct. 2013 (B). Vertical bars indicate least significant difference (LSD) values $(P=0.05)$ for treatment comparisons at a given day of treatment.
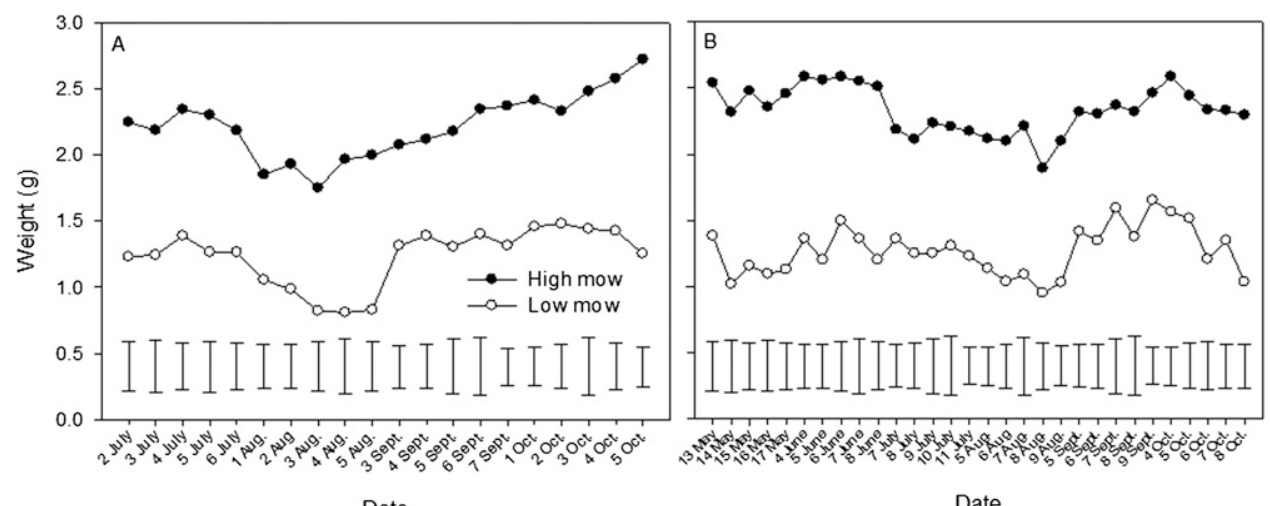

Date

Date

Fig. 6. Shoot biomass (collected within the area of gas exchange measurement) of kentucky bluegrass mowed at high $(7.6 \mathrm{~cm})$ and low $(3.8 \mathrm{~cm})$ heights from July to Oct. 2013 (A) and May to Oct. 2013 (B). Vertical bars indicate least significant difference (LSD) values $(P=0.05)$ for treatment comparisons at a given day of treatment. whether there is a carbon gain or carbon loss from a plant ecosystem (Lohila et al., 2003). Grass species of natural grasslands in northern temperate climates, such as thickspike wheatgrass (Elymus lanceolatus) and western wheatgrass (Pascopyrum smithii), showed enhanced carbon gain during spring and autumn months, whereas carbon gain is minimal or carbon loss occurs to a greater extent during summer months (Flanagan et al., 2002). Results from the present study with managed turfgrass stands demonstrated that while respiration rate of the whole turfgrass system (shoots, roots, and soil) may increase upon very high temperatures, as noted in 2013, the plant shift from carbon gain to carbon loss is mainly due to a decrease in canopy $\mathrm{Pn}$ as temperatures increased above $24^{\circ} \mathrm{C}$. The ratio of $\mathrm{R}_{\text {total }}$ to canopy $\mathrm{Pn}$ indicated high capacity for carbon gain (values of 1.2 to 1.7 ) from 23 to $28^{\circ} \mathrm{C}$ for HM plots whereas LM plots had less capacity for carbon gain within the same temperature range. Furthermore, low mowing hindered canopy Pn and accelerated carbon loss (values below 1.0) under very high temperatures and suboptimal temperatures below $18{ }^{\circ} \mathrm{C}$ (commonly referred to as chilling stress). Specific reasons for this shift in carbon dynamics may be numerous, but it is generally well-accepted that photostudy (Huang and Gao, 2000). However, the optimal temperature range for canopy Pn of cool-season turfgrasses, such as kentucky bluegrass, under field conditions is not well documented in previous literature. In this study, the highest canopy Pn occurred between 22 and $24{ }^{\circ} \mathrm{C}$ under both LM and HM in both years, suggesting this temperature range could be best for kentucky bluegrass carbon fixation under field management conditions. The optimal temperature for beneficial gas exchange corresponded to times of year when TQ and shoot biomass were highest at both mowing heights. The decline in canopy Pn and hindrance of carbon uptake into the plant system upon higher temperatures corresponded to times of year when TQ and shoot biomass were lowest at both mowing heights. Lowering mowing height accelerated the decline in canopy Pn and subsequently TQ and shoot biomass under increasing temperatures above the optimal ranges for plant growth, though the specific temperature range in which the decline occurred was not altered or shifted for LM plots.

The adverse effects of different mowing heights on turfgrass performance under different temperatures have been investigated in previous studies (Carrow, 1996; Salaiz et al., 1995), though little information is known as to the interactive effect of mowing height and increasing temperature governing carbon balance in a perennial turfgrass stand. Plant photosynthetic carbon uptake and ecosystem (plant and soil) respiratory carbon loss determine synthetic activities are more sensitive and inhibited to a greater extent compared with respiratory activities upon temperature extremes (Taiz and Zeiger, 2010). Our results suggested that kentucky bluegrass maintained positive carbon gain during spring and autumn and carbon loss during summer months. The net carbon loss with increasing temperatures could be a major contributer to the observed decline in TQ and shoot biomass during summer months.

Using measuring techniques for canopy Pn and turfgrass ecosystem respiration rates similar to this study, Baird (2011) evaluated carbon fixation potentials of several cool-season turfgrass species and reported that kentucky bluegrass and perennial ryegrass (Lolium perenne) mixture had greater carbon fixation potential (estimated from canopy $\mathrm{Pn}$ and $\mathrm{R}_{\text {total }}$ ) than tall fescue (Festuca arundinacea) and fine fescue (Festuca rubra). Our results indicated that whether kentucky bluegrass stands fix or loss carbon depended on air temperature and was greatly affected by mowing height. Turfgrass stands at HM had increased Pn: $R_{\text {total }}$ and therefore plants were able to fix more carbon between 23 and $29{ }^{\circ} \mathrm{C}$ during 2012 and between 17 and $27^{\circ} \mathrm{C}$ during 2013. Alternatively, lower mowing height decreased the ratio of $\mathrm{Pn}$ to $\mathrm{R}_{\text {total }}$ and turfgrass plots exhibited carbon gain only between 22 and $26{ }^{\circ} \mathrm{C}$ during 2012 and between 17 and $23{ }^{\circ} \mathrm{C}$ during 2013. Results from both years suggested positive carbon balance were mainly due to significantly higher canopy 
Pn than $\mathrm{R}_{\text {total }}$ under cooler temperatures in kentucky bluegrass. As temperatures increased above the optimal range for plant growth, plots maintained at lower mowing height shifted to negative carbon balance sooner or at lower temperature compared with plots mowed at higher mowing height. In addition, Pn: $\mathrm{R}_{\text {total }}$ was less than 1.0 across most of the temperatures in LM plots, particularly during seasons with temperatures lower or higher than the optimal ranges, while the ratio was maintained above 1.0 for $\mathrm{HM}$ plots at most temperatures. These results indicated that reducing mowing height weakened the capacity of turfgrass stands to fix carbon and accelerated the potential for wasteful carbon loss.

In summary, kentucky bluegrass displayed significant decline in canopy Pn and subsequent decline in TQ and shoot biomass with increasing air temperature beyond $23-24{ }^{\circ} \mathrm{C}$ in both 2012 and 2013 and the decline was more pronounced when plots were mowed at lower height. Increasing temperatures combined with lower mowing height hindered total carbon gain by reducing canopy photosynthesis and promoted carbon loss by increasing respiration at very high temperatures. Increases in mowing height may effectively offset the deleterious effects of high temperature and maintain positive carbon balance within the turfgrass ecosystem. Further work may investigate the interactive effects of other management factors, such as mowing, fertilization, or irrigation, on carbon dynamics of turfgrass stands across seasons in various climatic regions.

\section{Literature Cited}

Baird, J.H. 2011. Researching golf's carbon footprint. U.S. Golf Assn. Green Section Rec. 49:1-4.

Bandaranayake, W., Y.L. Qian, W.J. Parton, D.S. Ojima, and R.F. Follett. 2003. Estimation of soil organic carbon changes in turfgrass systems using the CENTURY model. Agron. J. 95:558-563.

Beard, J.B. 1973. Turfgrass: Science and culture. Prentice Hall, Englewood Cliffs, NJ.

Carrow, R.N. 1996. Summer decline of bentgrass greens. Golf Course Mgt. 64:51-56.

Cole, V., C. Cerri, K. Minami, A. Mosier, N. Rosenberg, and D. Sauerbeck. 1996. Agricultural options for mitigation of greenhouse gas emissions, p. 744-771. In: R.T. Watson, M.C. Zinyowera, and R.H. Moss (eds.). Climate change 1995: Impacts, adaptations and mitigation of climate change: Scientific-technical analyses. Cambridge Univ. Press, Cambridge, UK.

DaCosta, M. and B. Huang. 2013. Heat-stress physiology and management, p. 249-278. In: J.C. Stier, B.P. Horgan, and S.A. Bonos (eds.). Turfgrass: Biology, use, and management. Amer. Soc. Agron., Crop Sci. Soc. Amer., Soil Sci. Soc. Amer., Madison, WI.
Flanagan, L.B., L.A. Wever, and P.J. Carlson. 2002. Seasonal and interannual variation in carbon dioxide exchange and carbon balance in a northern temperate grassland. Glob. Change Biol. 8:599-615.

Huang, B. and H. Gao. 2000. Growth and carbohydrate metabolism of creeping bentgrass cultivars in response to increasing temperatures. Crop Sci. 40:1115-1120.

Li, S-G., J. Asanuma, W. Eugster, A. Kotani, J-J. Liu, and T. Urano. 2005. Net ecosystem carbon dioxide exchange over grazed steppe in central Mongolia. Glob. Change Biol. 11:1941-1955.

Liu, X. and B. Huang. 2001. Seasonal changes and cultivar difference in turf quality, photosynthesis, and respiration of creeping bentgrass. HortScience 36:1131-1135.

Liu, X. and B. Huang. 2003. Mowing height effects on summer turf growth and physiological activities for two creeping bentgrass cultivars. HortScience 38:444-448.

Lohila, A., M. Aurela, K. Regina, and T. Laurila. 2003. Soil and total ecosystem respiration in agricultural fields: Effect of soil and crop type. Plant Soil 251:303-317.

Milesi, C., S.W. Running, C.D. Elvidge, J.B. Dietz, B.T. Tuttle, and R.R. Nemani. 2005. Mapping and modeling the biogeochemical cycling of turf grasses in the United States. Environ. Mgt. 36:426-438.

Qian, Y. and R.F. Follett. 2002. Assessing soil carbon sequestration in turfgrass systems using long-term soil testing data. Agron. J. 94:930935.

Qian, Y., R.F. Follett, and J.M. Kimble. 2010. Soil organic carbon input from urban turfgrasses. Soil Sci. Soc. Amer. J. 74:366-371.

Qian, Y.L., W. Bandaranayake, W.J. Parton, B. Mecham, M.A. Harivandi, and A.R. Mosier. 2003. Long-term effects of clipping and nitrogen management in turfgrass on soil organic carbon and nitrogen dynamics. J. Environ. Qual. 32:1694-1700.

Salaiz, T.A., G.L. Horst, and R.C. Shearman. 1995. Mowing height and vertical mowing frequency effects on putting green quality. Crop Sci. 35:1422-1425.

Solomon, S., D. Qin, M. Manning, M. Marquis, K.B. Averyt, and M. Tignor. 2007. IPCC: Climate change 2007: The physical science basis. In: H.L. Miller and Z. Chen (eds.). Contribution of working group I to the fourth assessment report of the intergovernmental panel on climate change. Cambridge Univ. Press, Cambridge, UK/ New York, NY.

Steinke, K. and E.H. Ervin. 2013. Turfgrass ecology, p. 347-381. In: J.C. Stier, B.P. Horgan, and S.A. Bonos (eds.). Turfgrass: Biology, use, and management. Amer. Soc. Agron., Crop Sci. Soc. Amer., Soil Sci. Soc. Amer., Madison, WI

Taiz, L. and E. Zeiger. 2010. Plant physiology. 5th ed. Sinauer Associates, inc, Sunderland, MA.

Townsend-Small, A. and C.I. Czimczik. 2010. Carbon sequestration and greenhouse gas emissions in urban turf. Geophys. Res. Lett. 37:1-5.

Turgeon, A.J. 2008. Turfgrass management. 8th ed. Pearson Prentice Hall, Upper Saddle River, NJ.

$\mathrm{Xu}, \mathrm{L}$. and D.D. Baldocchi. 2004. Seasonal variation in carbon dioxide exchange over a Mediterranean annual grassland in California. Agr. For. Meteorol. 123:79-96. 